\section{A systems approach to navigating food security during COVID-19: Gaps, opportunities, and policy supports}

\author{
Alesandros Glaros, ${ }^{\mathrm{a}}$ * Chloe Alexander ${ }^{\mathrm{b}}$ \\ University of Guelph
}

Jodi Koberinski, ${ }^{\mathrm{c}}$ Steffanie Scott, ${ }^{\mathrm{d}}$ Stephen Quilley ${ }^{\mathrm{e}}$

University of Waterloo

Zhenzhong Sif

Balsillie School of International Affairs

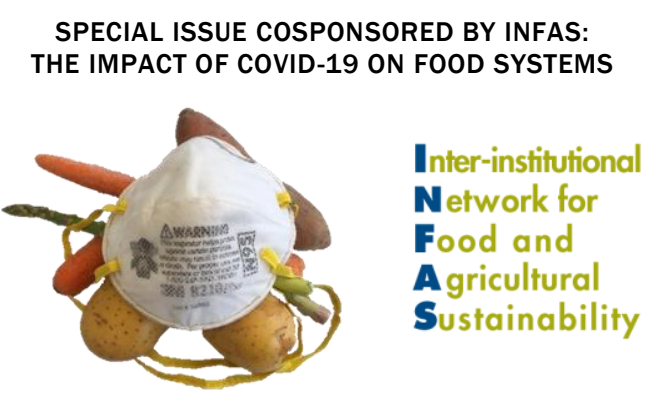

Submitted December 9, 2020 / Revised February 12 and March 4, 2021 / Accepted March 5, 2021 /

Published online April 8, 2021

Citation: Glaros, A., Alexander, C., Koberinski, J., Scott, S., Quilley, S, \& Si, Z. (2021). A systems approach to navigating food security during COVID-19: Gaps, opportunities, and policy supports. Journal of Agriculture, Food Systems, and Community Development, 10(2), 211-223. https://doi.org/10.5304/jafscd.2021.102.051

Copyright (C) 2021 by the Authors. Published by the Lyson Center for Civic Agriculture and Food Systems. Open access under CC-BY license.

\author{
Abstract \\ The COVID-19 pandemic has highlighted a series \\ of concatenating problems in the global production \\ and distribution of food. Trade barriers, seasonal \\ labor shortages, food loss and waste, and food \\ a * Corresponding author: Alesandros Glaros, Ph.D. candidate, \\ Department of Geography, Environment and Geomatics, \\ University of Guelph; 50 Stone Road East; Guelph, Ontario, \\ N1G 2W1 Canada; +1-905-518-6160; aglaros@uoguelph.ca \\ b Chloe Alexander, Ph.D. candidate, Ph.D. candidate, \\ Department of Geography, Environment and Geomatics, \\ University of Guelph; 50 Stone Road East; Guelph, Ontario, \\ N1G 2W1 Canada; calexa09@uoguelph.ca \\ c Jodi Koberinski, Ph.D. Candidate, Department of \\ Geography and Environmental Management, University of \\ Waterloo; 200 University Ave. West; Waterloo, Ontario, N2L \\ 3G1 Canada; jodiatuw@gmail.com \\ d Dr. Steffanie Scott, Professor, Department of Geography \\ and Environmental Management, University of Waterloo; 200 \\ University Avenue West; Waterloo, Ontario, N2L 3G1 \\ Canada; sdscott@uwaterloo.ca
}

safety concerns combine to engender vulnerabilities in food systems. A variety of actors-from academics to policy-makers, community organizers, farmers, and homesteaders-are considering the undertaking of creating more resilient food systems. Conventional approaches include fine-tuning existing value chains, consolidating national food

\footnotetext{
e Dr. Stephen Quilley, Associate Professor, School of Environment Resources and Sustainability, University of Waterloo; 200 University Avenue West, Waterloo, Ontario, N2L 3G1 Canada; squilley@,uwaterloo.ca

${ }^{\mathrm{f}}$ Dr. Zhenzhong Si, Postdoctoral Fellow, Balsillie School of International Affairs; 67 Erb Street West; Waterloo, Ontario, N2L 6C2 Canada; sizhenzhong@gmail.com
}

\section{Disclosures}

Alesandros Glaros is a contract-based Research Assistant for the Open Food Network-Canada.

Jodi Koberinski is co-chair of the Food Systems Roundtable Waterloo Region and engages in community development and networking efforts to educate and encourage policy that reflects sustaining food systems values. 
distribution systems and bolstering inventory and storage. This paper highlights three alternative strategies for securing a more resilient food system, namely: (i.) leveraging underutilized, often urban, spaces for food production; (ii.) rethinking food waste as a resource; and (iii.) constructing production-distribution-waste networks, as opposed to chains. Various food systems actors have pursued these strategies for decades. Yet, we argue that the COVID-19 pandemic forces us to urgently consider such novel assemblages of actors, institutions, and technologies as key levers in achieving longer term food system resilience. These strategies are often centered around principles of redistribution and reciprocity, and focus on smaller scales, from individual households to communities. We highlight examples that have emerged in the springsummer of 2020 of household and community efforts to reconstruct a more resilient food system. We also undertake a policy analysis to sketch how government supports can facilitate the emergence of these efforts and mobilization beyond the immediate confines of the pandemic.

\section{Keywords}

Food System, Local Food, Food Waste, Resilience, COVID-19, Pandemic, Community Development

\section{COVID-19 and Food System Resilience}

The coronavirus pandemic has highlighted major weaknesses in our food supply chains: a lack of local, skilled, agricultural labor, and lack of infrastructure for robust networks of regional production, distribution, and consumption. Simultaneously, for the first time since the Second World War (in countries like Canada and the United States), there was real fear of widespread empty supermarket shelves. Significant losses in household income have reignited concerns over hunger, globally (Dickinson, 2020). Alongside more acute public health concerns (Cullen, 2020), food security has emerged as a key medium- to long-term policy priority in the face of COVID-19 in most parts of the world. In a more general sense, the pandemic raises questions about the trajectory of globalization and integration which has dominated innovation and policy in food systems since the 1980s (see Harvey, Quilley, \& Benyon, 2002).
Considering these challenges, academics and policy-makers are advocating for greater levels of food self-sufficiency and resilience (Gordon, 2020; Richardson, 2020). Some researchers argue that this can be achieved through disrupting just-intime food systems, maintaining larger staple crop inventories, and bolstering regional supply chains (Fraser, 2020). Other academics suggest that we must further fine-tune our just-in-time supply chains using information and communication technologies (ICTs), big data, artificial intelligence, and automated equipment. In doing so, Galanakis (2020) suggests that we minimize the chance for supply chain disruption and reduce human contact during the agricultural process. Each of these strategies: maintaining larger inventories, bolstering regional food systems, and fine-tuning existing supply chains have already vied for policy support in the past several decades (Fraser et al., 2016).

For decades, academics, activists, and practitioners have been calling for systems-level changes that move beyond those business-as-usual strategies described above (Roberts \& Brandum, 1995). Importantly, conversations around food system resilience need to critically consider political dimensions: resilience for whom, of what, to what, where, when, and why (Meerow \& Newell, 2019). The pandemic has brought some of these political issues to the fore: the right to food; arguments for wealth redistribution, basic income, and holding corporations accountable for their negative externalities, among others (James et al., 2021). Simultaneously, the pandemic has ignited debates over the prospect of 'peak globalization' (Enderwick \& Buckley, 2020) and what a necessarily more regional or localized politics may look like (Quilley, 2012). Yet, the question remains: what modes or types of production, distribution, consumption, and waste management could have purview in a more 'self-sufficient', post COVID-19 food system? What assemblages of actors, market institutions, and technologies could and/or will have important roles in this future?

In this paper we use a systems lens (BlayPalmer, Carey, Valette, \& Sanderson, 2020; Devereux et al., 2020) to sketch different opportunities through which to develop a more resilient food system. These opportunities include environ- 
ments in which the following three conditions are met. First, it is critical that there is a diversity of participating actors with significant decisionmaking autonomy (Rotz \& Fraser, 2015). Decisionmaking autonomy allows for actors to respond and adapt in a timely manner to address place-specific needs, but it is often hampered by concentration and consolidation within the food system. Second, we emphasize that policymaking and governance processes capture interactions across multiple scales, from individuals and households to national economies (Tendall et al., 2016). Failing to recognize interactions between scales increases the risk of overlooking opportunities to foster food security, or policies and institutions that prevent individuals from exercising agency. Third, we stress that it is critical for relocalization to be recognized as a necessary but insufficient goal for food system transformation. Trends toward vertical integration and increasing global flows of goods and information propagate risk over greater scales (HomerDixon et al., 2015), highlighting the need for more distributed food system networks. Whereas definitions of sustainable food systems commonly emphasize the three pillars of food security (supply, access, utilization) and the well-being of the environment, our definition of food system resilience considers the interactions between actors and how they are enabled (or inhibited) by policy to pursue food security goals.

We have two objectives:

(1) To sketch three different opportunities that may have significant roles in developing a more resilient food system. These opportunities are by no means 'new' and are widely discussed in alternative food systems literature. However, the pandemic context within which they are currently debated has made them more prescient and accelerated the pace of their innovation. The opportunities we explore disrupt the existing system in relation to: (a) increasing the means and places to grow food; (b) rethinking food waste; and (c) disrupting supply chains by building supply networks.

(2) To conduct a brief analysis of policies that support and hinder these opportunities and advance several policy recommendations through which to leverage these three opportunities.
We argue that the COVID-19 pandemic represents itself as a moment of crisis through which novel assemblages of actors, institutions, and technologies are addressing food insecurity, particularly at individual household and community-scales. To address the gaps in food policy that our analysis has highlighted, we recommend that policy-makers support community and household-based efforts that have emerged as key levers for regional food self-sufficiency. While often but not always organized around principles of reciprocity and redistribution, these community and household initiatives are what some scholars might characterize as "reformist" or "progressive", rather than "radical" (Gimenez \& Shattuck, 2011). In other words, these interventions may not directly tackle systemic issues around rights, redistribution, and responsibility described above (James et al., 2021). Yet, we contend that these responses are key to building more resilient food systems in the long-term.

\section{Scale, Interactions, Moments of Crisis and Opportunity}

Given the focus of this paper on resilience, we draw from socio-ecological systems resilience literature to inform our understanding of the food system. Food systems literature often conceptu. alizes the system at a global level (e.g., Rotz \& Fraser, 2015; Homer-Dixon et al., 2015). Yet, it is important to consider interactions across scales; a nested panarchy framework (Gunderson \& Holling, 2002) emphasizes the cross-scalar interactions that define food system outcomes, from an individual to global level, and vice versa. Using this framework, Tendall et al (2015) argue that food system resilience can be built through management at a national or regional level, the level of the individual commodity chain, or the level of the individual actor (e.g. smallholder, consumer).

COVID-19 has generated new and renewed scholarly interest in defining, measuring, reporting, and fostering food system resilience. Emphasis in scholarly articles has been placed on three different dimensions of food system resilience. The first is ensuring an adequate food supply. This involves a suite of strategies, including reducing cross-border trading friction, ensuring national stockpiles of food, and addressing labor shortages caused by the 
pandemic in order to ensure adequate production levels (Chen \& Mao, 2020; Savary et al., 2020). Second, emphasis has been placed on ensuring adequate demand. Concerns in this realm center around the loss of consumer purchasing power or access to food, incurred through individual and household loss of income and 'ripple effects' to other food system actors relying on those consumers (Béné, 2020; Devereux et al., 2020). This is in addition to physical barriers to access, such as store closures or reduced mobility, and associated microeconomic effects due to decreased food retailing competition (Ihle, Rubin, Bar-Nahum, \& Jongeneel, 2020; Savary et al., 2020). The third type of scholarly analysis of food system resilience emphasizes place-based and scale-appropriate responses to this and future crises. This perspective stresses that over-reliance on global supply chains has resulted in a state of local food system precarity, particularly for the most poor and vulnerable populations, and promotes agroecological and regenerative models of food production (Altieri \& Nicholls, 2020; Blay-Palmer et al., 2020). This perspective argues for food systems, "that are sensitive to ecological and social places. Food system resilience is more likely to be fostered through a combination of first local, including informal, and regional and then global supply chains" (Blay-Palmer et al., 2020, p. 517).

In this paper we acknowledge these diverse perspectives while being cognizant of the systemic nature of food system resilience. As discussed above, we center our approach to food system resilience around the relationships between actors and government policies that facilitate or inhibit their adaptive potential. The pandemic presents an opportunity for a deeper level of analysis reflecting on mutual aid capacity promoted through individual and community-level projects. This brief review and analysis of local food programs and policies provides insights that would be missed with a transactional lens alone, given the significance of informal support systems for food security that have captured the attention of scholars and policy-makers since March 2020 (HaynesMaslow, Hardison-Moody, \& Byker-Shanks, 2020), and the suite of local policy responses that have arisen in context of existing relationships and networks (analyzed in the following sections). By situating our focus at a more localized level we focus on concrete opportunities for policy and programs that have emerged during the pandemic, citing individual, community, and municipal responses to food security needs. These opportunities are often overlooked entry-points for immediate emergency relief in moments of crisis. While the three opportunities we describe are by no means 'new' and have been promoted for years, they have played sizable roles in responding to acute pandemic needs. We suggest that their promotion during and beyond the confines of lockdown procedures is vital to securing more resilient food system futures.

\section{Three Opportunities}

Producing More, Everywhere, in $A$ ny $W$ ay COVID-19 has engendered a new crop of enthusiasts turning to gardening_amid food security and mental health concerns (Hansen, 2020; Lal, 2020). A recent report models that up to 250,000 people could be fed in Montreal during the growing season using community gardens and individual household gardening systems (Duchemin, 2020). Growing food in urban and peri-urban areas can take on multiple forms with varying degrees of intensity. It is widely recognized that allotment gardens and various forms of urban agriculture (UA) are key strategies used by households in moments of crisis (Barthel \& Isendahl, 2013). Scholars commonly cite Cuba as an exemplar for how UA can be institutionalized and coordinated to maintain stable supplies of domestic food amid a crisis (Altieri et al., 1999). Another celebrated case is the prominence of highly productive, smallscale production in dachas in Russia. Since 1991, dachas have played massive roles in responding to food crises and bolstering national agriculture production. An estimated $40 \%$ of total Russian production took place at the household-level in 1995 (Hamilton et al., 2014). Decentralized, often small or medium-in-scale, food production strategies make incredibly efficient use of public and private land, as well as local waste and compost resources (Colding \& Barthel, 2013). Rooftop gardens and vertically integrated green spaces have 
grown in number in major cities and are even now incentivized ${ }^{1}$ by some municipalities for future development.

Outside of these more commonly discussed examples of UA, a suite of novel technologies and approaches are emerging that could substantially contribute to local food systems post-pandemic. The vertical farming industry, for example, has blossomed in recent years. The sterile, purple-lightbathed plant factories that initially began to emerge five to ten years ago have been complemented by community-based microgreen farms, DIY garage aquaponics systems, shipping-container driveway gardens, and building-integrated systems across the world (Specht et al., 2015; Specht et al., 2019). Furthermore, in-vitro protein production: a new technology that produces meat protein in bioreactors without the slaughter of animal, can theoretically move livestock production into urban areas. This technology was developed at a whopping cost-perburger patty seven years ago but has nearly reached middle-class markets, ${ }^{2}$ notwithstanding significant regulatory and consumer acceptance hurdles (Bryant \& Barnett, 2018; Stephens et al., 2018). There is even discussion of household and regional-scale in-vitro protein production systems as research and development continues (Miller, 2020). Less science fiction in tenor, small-scale urban and peri-urban insect farms are common in many parts of the world. Primary barriers to the development of entomophagy as a viable food security strategy in North America are psychological and sociological, rather than technical, in nature (Sexton, Garnett, \& Lorimer, 2019). Any post COVID-19 strategy to bolster local food production must consider implementing incentives and addressing regulatory barriers for these emerging foods and technologies.

Pre-pandemic, UA was often pursued by scholars and policy-makers in Canada and the
United States for its educational, mental, physical, and environmental health benefits, rather than necessarily for food security reasons (Badami \& Ramankutti, 2015). In moments of crisis, however, UA has in fact been promoted by governments to ensure adequate supplies of food, similar to war garden efforts during the Great Wars (Barthel, Parker, \& Ernston, 2013). With various governments' promotion of food production on public land, and even in some cases distribution of food growing kits ${ }^{3}$ to the public, there has been a marked shift in discourse (Food Secure Canada, 2020). Yet, in some cases these developments were met with resistance from public officials. As one example, Ontario banned the use of community gardens at the outset of the pandemic due to social distancing public health recommendations; it took concerted lobbying and petitioning from key local and regional actors to reverse this ban (Felice, 2020a).

While significant attention is rightly being directed to the challenges that farmers face, there is potential for additional support for household and community-based systems of food production.

How can policy facilitate the capabilities of households and communities to produce food, even outside the immediacy of crisis? We suggest that policies may take the form of financial support for community or household projects, educational resources, and network building to both bolster production and distribute surplus. Such forms of UA are likely to be a combination of small to medium-scale householding projects and community-based endeavors of varying capital intensity. Moreover, these supports need to be cognizant of emerging technologies (e.g., vertical farming, food forestry, rooftop gardens) and foods (e.g., alternative proteins). Already, governments have responded to the call for such community-based endeavors with programs such as the Local Food

\footnotetext{
${ }^{1}$ The Municipality of Toronto has an incentive program to support the installation of green and cool roofs on houses and buildings (https://www.toronto.ca/services-payments/water-environment/environmental-grants-incentives/green-your-roof/).

${ }^{2}$ Future Meat company estimates that they can reduce the price of cultured meat to US $\$ 10 / \mathrm{kg}$ by the year 2022

(https://www.cnbc.com/2019/10/10/future-meat-technologies-a-lab-grown-meat-start-up-raises-14-million-dollars.html).

${ }^{3}$ The city of Brampton ran its second annual Backyard Garden program in 2020, supporting "the Mayor's COVID-19 Social Support

Task Force's focus on food security" (https://www.brampton.ca/EN/City-Hall/News/Pages/Media-Release.aspx/858). In partnership with an NGO, the city of Ottawa distributed growing kits directly to the public in response to the pandemic (https://justfood.ca/garden2020/).
} 
Infrastructure Fund ${ }^{4}$ to encourage NGOs to engage in activities to expand capacity to produce, process, and preserve Ontario's harvest. Further examples can be drawn from policy developments to accommodate backyard hen-keeping in major cities, where changes in zoning rules, the development of animal husbandry education programs, and bylaws have been implemented. ${ }^{5}$ Further investigations regarding successful projects and the context in which they arise could help inform the ways municipalities support ongoing engagement. Moreover, this research would assist with the communication of program or project value over time to policy-makers and city councils who may in turn fund these sustaining food systems efforts.

\section{Rethinking Waste}

COVID-19's disruption to the food system has exposed how sensitive the current food system's distribution chains are to global changes, with a significant consequence being exorbitant levels of food loss and waste. Images of milk dumping, mountains of surplus potatoes, and produce rotting in fields unharvested demonstrate the scale at which food is being lost and wasted as actors in the food system attempt to adapt (Brigham, 2020; Clapp, 2020; Gangitano, 2020; Yaffe-Bellany \& Corkery, 2020). Juxtaposed with empty shelves (as a result of panic buying) and raised food insecurity rates, ${ }^{6}$ it is clear that this adaptation process is slow and imprecise. Preliminary results indicate that household waste decreased during the pandemic, driven in part by concerns over domestic waste management capacity (Pappalardo et al., 2020), food availability, and loss of income (Jribi, Ben Ismail, Doggui, Debbabi, 2020). By disrupting daily routines and patterns of behavior, the pandemic is clearly presenting individual households and communities with an opportunity to become aware of, evaluate, and reduce their food waste.

To fill the major gaps in how our food system generates and manages waste during the pandemic, communities and individuals have both created new networks and built up existing networks to redistribute surplus food in order to reduce food waste and support people who are food insecure. This has resulted in increased interest in CSAs (Coppolino, 2020), online farmers' markets, community-led gleaning of local farms, food sharing among individuals (both in person and through apps) (Wray, 2020), and the repurposing of commercial kitchens for charity-related purposes (Littman, 2020). The uptick in gardening and excess food that has resulted from panic buying has motivated some people to manage their personal food waste using composting, and vermicomposting (Anderson, 2020). Of course, these creative responses to addressing food insecurity and food waste were spurred by government lockdown procedures that restricted the operation of many charitable organizations (Peters, 2020).

During the pandemic, government interest and action for addressing food security at the individual and community level has increasingly involved redistributing surplus food that can no longer be sold in other sectors of the food system (such as grocery stores) to charitable organizations that feed food insecure people (Ontario Government, 2020). While this method can provide people with temporary access to food and reduce some food waste, it addresses food insecurity through charity rather than political action and allows food businesses to externalize their waste (Riches, 2011). Some governments, including Wuhan and Shanghai, among other Chinese cities, ${ }^{7}$ have also created stringent food waste guidelines for the public since COVID-

\footnotetext{
4 The Local Infrastructure Fund is a five year, federally funded, US $\$ 50$ million initiative to support community-based, not-for-profit organizations involved in food security initiatives in Canada.

${ }^{5}$ UrbanHens'TO Pilot Program was developed and implemented March 2018, running until March 2022, whereby residents in select neighborhoods can raise hens for eggs while abiding by city guidelines (https://www.toronto.ca/community-people/animals-pets/pets-in-the-city/backyard-hens/).

${ }^{6}$ According to a survey conducted in May 2020 by Statistics Canada, nearly one in seven Canadians indicated that they lived in a household experiencing food insecurity over the past 30 days (https://www150.statcan.gc.ca/n1/pub/45-28-0001/2020001/article/00039-eng.htm).

${ }^{7}$ Wuhan, China's 'N-1 policy' urges restaurants to require groups to order one dish less than the number of diners. The N-1 policy has been met with controversy, given cultural stigma around 'clean plates' as a sign of poor hosting, as well as food waste generated by
} 
19. Such policies, though potentially less politically palatable in other nations, could be implemented through less punitive means such as tax or marketbased incentives. While some governments recommended stocking up on food to avoid non-essential trips, organizations such as the FAO recommend consistent messaging around adequate food supplies in order to avoid stockpiling (FAO, 2020). Such inconsistencies in recommendations likely have an impact on household food waste, given lack of education or guidelines around efficient food use and proper storage and handling techniques during crises (Cosgrove, Vizcaino, \& Wharton, 2021).

Policy support at the individual and community level should acknowledge that the causes of food waste are complex and create a multi-faceted approach to tackling it (Thyberg \& Tonjes, 2016). This support can take the form of expanding organic and food waste collection services (especially for rural and multi-unit residences) (Hebrok $\&$ Boks, 2017); educating people about food waste and providing them with techniques to prevent it (such as how to properly store food, plan meals, purchase food, cook, and use leftovers) (do Carmo Stangherlin \& Dutra de Barcellos, 2018); supporting research that measures food waste, examines the causes of it, and/or creates interventions to reduce it (Reynolds et al., 2019); and subsidizing small scale biodigesters, compost bins, and vermicomposting kits. Importantly, policy development that addresses food waste in other sectors of the agri-food system, such as clarifying rules around best before dates (Hebrok \& Boks, 2017), can help reduce food waste at the individual and/or community level (Schanes, Dobernig, \& Gözet, 2018). Capitalizing on the increased consumer awareness of food waste caused by the pandemic through information campaigns around best before dates is required (Principato, Secondi, Cicatiello, \& Mattia, 2020). The pandemic has highlighted the complexity of where, how, and why food gets wasted, beyond solely the household and community scale. Policies that address food waste across the food system are needed, including interventions to facilitate greater collaboration between farmers, processors, and packaging companies (FAO, 2020).

\section{Networks, Not Chains}

With worries over supply chain disruption, numerous community groups have risen to build networks to address threats to food security. In North America, over the course of the pandemic, there has been an unprecedented growth in care-mongering groups $^{8}$ and resource-sharing pages. New sourdough bread bakers have gotten to work, sharing loaves and even pinning starter mixes in plastic baggies to telephone poles (Gee, 2020). Plant and seed swaps have engaged a growing network of online exchangers (read: not shoppers). Place- and community-based networks_-both_pre-existing and new-have created robust systems of exchange, where those most in-need can access resources in a timely manner. Such systems of exchange have leveraged social media and digital networks technologies to address food security concerns.

These distributed systems of exchange, though by no means 'new', have risen in prominence and hold significant potential to bolster regional food system self-sufficiency in a post-COVID world. Beyond care-mongering groups, several initiatives hold much promise. For example, the construction of outdoor brick ovens for public baking, as well as gleaning and "grow-a-row" efforts, have potential to contribute to knowledge building, food exchange, and food security (Piotrowski, 2019). Similarly, food forests have risen in popularity in many Canadian cities despite lack of meaningful municipal encouragement (Kowalski \& Conway, 2019). These efforts seek to integrate berry bushes, fruit trees, and vegetable cultivation into public areas, whereby all community members can access these resources. A slew of mapping applicationshas emerged (or grown in reach) to catalogue, in real-

\footnotetext{
large banquets hosted by officials. Shanghai enforces penalties on individuals and companies who fail to sort their organic waste (https://www.bbc.com/news/world-asia-china-53761295).

${ }^{8}$ An online community group, often hosted on Facebook, where those in isolation can reach out to share food and food production resources, find point persons, and organize pickups and drop-offs (https://www.cbc.ca/player/play/1711703619777).
} 
time, inventories of such public (and, with permission, private) sources of food, through crowdsourcing. ${ }^{9}$ Online marketplaces such as the Open Food Network have ballooned in reach almost overnight (Tucker, 2020). In China, voluntary buying groups built through social media applications were the major source for food access during the lockdown, addressing gaps in state and private-led food access platforms (Si, Qi, Dai, Zhong, \& Crush, 2020). Re-embedding the process of market exchange in place-centered social relations of mutual obligation and reciprocity, these innovations are 'Polanyian' (Hodgson, 2017; Polanyi, 1957a; 1957b; 2001; Quilley, 2012) in tenor and intimate a more transparent and viscous pattern of market exchange.

COVID-19 motivates us to reimagine food security from, singularly, a tightly coordinated supply chain policy priority, propped up by food banks (Gimenez \& Shattuck, 2011; Riches, 2018), to a network that is comprised of state, grassroots, public or citizen groups, and private entities. Furthermore, network-type technologies (e.g., crowdsource mapping) can engage a variety of actors (including those cut out of conventional supply chains) to address food insecurity challenges, as detailed above. For example, an array of farmers markets, partnering with public health authorities, have mobilized on digital platforms to help farmers maintain diverse revenue streams. ${ }^{10}$ This successful mobilization occurred despite confusion over designating farmers markets as essential services at the outset of the pandemic in Ontario (Felice, 2020b). The designation of initiatives such as farmers markets and other 'alternative' food procurement streams as essential services is critical, both during and beyond the duration of the pandemic. Funding, technical, and zoning support for physical and digital infrastructure for such community-based initiatives is integral.

\section{Conclusion}

This is a unique historical moment, justifying stronger state support for farmers and bolstering regional food system infrastructure. However, it's also an important moment to reflect on 'roads less travelled' to achieving food security and resilient food systems. With emerging technologies, business models, and the rise of community-scale activism that this crisis has engendered, we can reimagine new scales and systems of food production, distribution, consumption, and waste management. Central to this is leveraging the capabilities of individuals and households to participate in the food system as producers as well as consumers. This type of multi-actor, cross-scale collaboration is already occurring in cities such as Toronto, Ontario. During the COVID-19 pandemic, the Toronto Food Policy Council has extensively mobilized. It has enhanced civil society-municipal government collaboration, facilitated the deployment of resources to support at-risk communities, and promoted network and infrastructure development to connect local producers with urban markets (Friedmann 2020). Black Food Toronto was a response designed to get public food in the form of a weekly produce basket to low-income Black people in Toronto hit extra hard by the pandemic, demonstrating that such public food is possible.

We recognize that food self-sufficiency is a relative (not an "either-or") policy goal, alongside a multitude of forms of production, distribution, consumption, and waste management across scales and between nations (Clapp, 2017). Nevertheless, we suggest that the global pandemic has justified the potential for smaller-scale, more circular and autarkic approaches to food security that have been vying for state support for decades. The exact forms in which these new systems occur will depend on the people and places that organize to make them. Building networks and brokering relationships between diverse actors in production,

\footnotetext{
${ }^{9}$ Falling Fruit is a crowd-sourced, open-source inventory of edible plants, aiming to be the most comprehensive of its kind in the world (http:// fallingfruit.org/).

10 The Ottawa farmers market offered an online market place and organized pickups at the beginning of the 2020 season, as shop fronts were not allowed to open (https://ottawa.ctvnews.ca/ottawa-markets-launches-online-farmers-market-during-covid-19pandemic-1.4924377).
} 
distribution, and food waste systems, especially across scales, will be critical. As one example, in Canada, one such emerging system is a network of grassroots food policy councils, front line food sovereignty and food security workers, and community food leadership. The Food Communities Network was already in the process of launching after years of relationship-building and case-making for a formal national network when the pandemic hit. This network was an instrumental piece of social infrastructure for speeding up the opening of community gardens, farmers markets, and new distribution options for communities on lock down across Canada. Indigenous-led programs, such as those pursued through the Indigenous Food Circle in Thunder Bay, Ontario, often center around principles of reciprocity and right to self-determination of food: "[...] rooted in the theory and practice of food sovereignty, emphasizing self-determination and a re-connection to land-based food systems" (Levkoe, Ray, \& Mclaughlin 2019, p. 111). Such programs provide instructive guidance for settler populations where food is viewed as a commodity.

Individual and community-level responses to food insecurity during the pandemic have been rapid, effective, and numerous, despite some policies that have actively dissuaded their emergence. Rather than actively inhibit or neglect these individual and community-led efforts in the months that follow, policy needs to both recognize and incentivize food production in urban areas; leverage momentum in decreased household food waste, while addressing perverse incentives that result in food loss; and facilitate the brokering of networks between local food system actors, especially those most food insecure. These three strategies are not new but have reemerged as key levers to promote food security during the pandemic. These three strategies are also largely prefigurative, in that though they rose in significance during the pandemic, they point to possible futures only without concerted policy efforts to incentivize, maintain, and promote their emergence. Yet, we argue, the pandemic has forced policy-makers to recognize these opportunities as key to any food systems transformation for long-term resilience.

This paper focuses on the immediate questions of increasing food production and access locally as a priority response under pandemic conditions. A future area of research would be the intersection of these approaches with sustainability frameworks such as Doughnut Economics. Moreover, our definition of food system resilience considers the adaptive measures and policies that shape and constrain individual and community-level responses to food insecurity. Future studies could consider the ecological dimensions of these emerging initiatives beyond pandemic conditions. Besides addressing immediate food security needs, how might the bolstering of smaller-scale production, distribution, and waste systems affect the long-term ecological wellbeing (or resilience) of agroecosystems, or minimize the ecological consequences of food system processes? Further research examining the climate and water "footprints" of various responses being pursued by civil society and entrepreneurs would add value to the policy discussions we highlight regarding food systems resilience. Finally, four areas for further investigation arise from this initial review of food system resilience in light of the crises raised by the COVID-19 pandemic: (a) implications for seed security; (b) the potential for pandemic recovery to promote climate resilience in agriculture; (c) the implications of worldwide disruptions in migrant labor on global harvests; and (d) implications for food justice initiatives designed to provide pathways to citizenship for the skilled farm labor upon whom food producers rely.

\section{References}

Altieri, M. A., Companioni, N., Cañizares, K., Murphy, C., Rosset, P., Bourque, M., \& Nicholls, C. I. (1999). The greening of the "barrios": Urban agriculture for food security in Cuba. Agriculture and Human Values, 16(2), 131-140. https://doi.org/10.1023/A:1007545304561

Altieri, M. A., \& Nicholls, C. I. (2020). Agroecology and the emergence of a post COVID-19 agriculture. Agriculture and Human Values, 37, 525-526. https://doi.org/10.1007/s10460-020-10043-7 
Anderson, P. (2020, March 27). Turning crap into gold: Why a composting habit will change your life. The Guardian. Retrieved from https://www.theguardian.com/lifeandstyle/2020/mar/28/turning-crap-into-gold-why-acomposting-habit-will-change-your-life

Badami, M. G., \& Ramankutty, N. (2015). Urban agriculture and food security: A critique based on an assessment of urban land constraints. Global Food Security, 4, 8-15. https://doi.org/10.1016/j.gfs.2014.10.003

Barthel, S., \& Isendahl, C. (2013). Urban gardens, agriculture, and water management: Sources of resilience for long-term food security in cities. Ecological Economics, 86, 224-234.https://doi.org/10.1016/j.ecolecon.2012.06.018

Barthel, S., Parker, J., \& Ernstson, H. (2013). Food and green space in cities: A resilience lens on gardens and urban environmental movements. Urban Studies, 52(7), 1321-1338. https://doi.org/10.1177/0042098012472744

Béné, C. (2020). Resilience of local food systems and links to food security - A review of some important concepts in the context of COVID-19 and other shocks. Food Security, 12, 805-822 https://doi.org/10.1007/s12571-020-01076-1

Blay-Palmer, A., Carey, R., Valette, E., \& Sanderson, M. R. (2020). Post COVID 19 and food pathways to sustainable transformation. Agriculture and Human V alues, 37, 517-519. https://doi.org/10.1007/s10460-020-10051-7

Brigham, K. (2020, May 19). Why coronavirus is causing a massive amount of food waste. CNBC. Retrieved from https://www.cnbc.com/2020/05/19/how-coronavirus-is-causing-mountains-of-food-waste.html

Bryant, C., \& Barnett, J. (2018). Consumer acceptance of cultured meat: A systematic review. Meat Science, 143, 8-17. https://doi.org/10.1016/j.meatsci.2018.04.008

Chen, K. Z., \& Mao, R. (2020). Fire lines as fault lines: Increased trade barriers during the COVID-19 pandemic further shatter the global food system. Food Security, 12, 735-738 https://doi.org/10.1007/s12571-020-01075-2

Clapp, J. (2017). Food self-sufficiency: Making sense of it, and when it makes sense. Food Policy, 66, 88-96. https://doi.org/10.1016/j.foodpol.2016.12.001

Clapp, J. (2020). Spoiled milk, rotten vegetables, and a very broken food system. The New York Times. Retrieved from https://www.nytimes.com/2020/05/08/opinion/coronavirus-global-food-supply.html

Colding, J., \& Barthel, S. (2013). The potential of 'Urban Green Commons' in the resilience building of cities. Ecological Economics, 86, 156-166. https://doi.org/10.1016/j.ecolecon.2012.10.016

Coppolino, A. (2020, June 13). Community Shared Agriculture a hot commodity as food security worries increase. CBC News. Retrieved from https://www.cbc.ca/news/canada/kitchener-waterloo/csa-community-shared-agricultureproduce-vegetable-box-andrew-coppolino1.5609637 ? fbclid=IwAR3HiRhv8RcPB9KJGMPSnlbG0DbPmEQcDnkA15jkTaTf0w-5oAe dG58HN4

Cosgrove, K., Vizcaino, M., \& Wharton, C. (2021). COVID-19-related changes in perceived household food waste in the United States: A cross-sectional descriptive study. International Journal of Environmental Research and Public Health, 18(3), 1104. https://doi.org/10.3390/ijerph18031104

Cullen, M. T. (2020). Covid-19 and the risk to food supply chains: How to respond? Retrieved from the Food and Agriculture Organization of the United Nations website: https://doi.org/10.4060/ca8388en

Devereux, S., Béné, C. \& Hoddinott, J. (2020). Conceptualising COVID-19's impacts on household food security. Food Security, 12, 769-772. https://doi.org/10.1007/s12571-020-01085-0

Dickinson, M. (2020). Food frights: COVID-19 and the specter of hunger. Agriculture and Human Values, 37, 589-590. https://doi.org/10.1007/s10460-020-10063-3

Do Carmo Stangherlin, I. \& Dutra de Barcellos, M. (2018). Drivers and barriers to food waste reduction. British Food Journal, 120(10), 2364-2387. https://doi.org/10.1108/BFJ-12-2017-0726

Duchemin, E. (2020). L'apport alimentaire de l'agriculture urbaine sociale aux villes en temps de crise: Le cas de Montréal [Billet]. AgriUrbain. Retrieved May 25, 2020, from https://agriurbain.hypotheses.org/4739

Enderwick, P., \& Buckley, P. J. (2020). Rising regionalization: Will the post-COVID-19 world see a retreat from globalization? Transnational Corporations Journal, 27(2). Retrieved from https://papers.ssrn.com/abstract $=3692317$

Felice, J. D. (2020a). Petition to identify community gardens as essential service. Sustain Ontario. Retrieved February 10, 2021, from https://sustainontario.com/2020/04/09/community-gardens-petition/ 
Felice, J. D. (2020b). OMAFRA letter confirms farmers' markets are essential and that non-food items can be sold in markets that primarily sell food. Sustain Ontario. Retrieved February 10, 2021, from https://sustainontario.com/2020/06/09/omafra-letter-farmers-markets-2020/

FAO. (2020). Mitigating risks to food systems during COVID-19: Reducing food loss and waste. https://doi.org/10.4060/ca9056en

Food Secure Canada. (2020). Growing resilience and equity: A food policy action plan in the context of Covid-19. Retrieved from https://foodsecurecanada.org/sites/foodsecurecanada.org/files/fsc - growing resilience equity 10 june 2020.pdf

Fraser, E. (2020). Coronavirus: The perils of our 'just enough, just-in-time' food system. The Conversation. Retrieved from https://theconversation.com/coronavirus-the-perils-of-our-just-enough-just-in-time-food-system-133724

Fraser, E., Legwegoh, A., KC, K., CoDyre, M., Dias, G., Hazen, S., .. Yada, R. (2016). Biotechnology or organic? Extensive or intensive? Global or local? A critical review of potential pathways to resolve the global food crisis. Trends in Food Science \& Technology, 48, 78-87. https://doi.org/10.1016/i.tifs.2015.11.006

Friedmann, H. (2020). Pandemic reflections from Toronto. Agriculture and Human Values, 37, 639-640. https://doi.org/10.1007/s10460-020-10098-6

Galanakis, C. M. (2020). The food systems in the era of the coronavirus (COVID-19) pandemic crisis. Foods, 9(4), 523. https://doi.org/10.3390/foods 9040523

Gangitano, A. (2020, April 17). Fresh produce goes to waste as coronavirus wrecks supply chains. The Hill. Retrieved from https:/ / thehill.com/business-a-lobbying/business-a-lobbying/493252-fresh-produce-goes-to-waste-ascoronavirus-wrecks

Gee, L. (2020). Coronavirus: San Francisco neighbors share sourdough starter at a social distance amid shelter-in-place baking craze. $A B C$ News. Retrieved from https://abc7news.com/how-to-feed-sourdough-starter-make-coronavirus-bread-recipe/6082517/

Giménez, E. H. \& Shattuck, A. (2011). Food crises, food regimes and food movements: Rumblings of reform or tides of transformation? The Journal of Peasant Studies, 38(1), 109-144. https://doi.org/10.1080/03066150.2010.538578

Gordon, L. J. (2020). The Covid-19 pandemic stress the need to build resilient production ecosystems. Agriculture and Human Values, 37, 645-646. https://doi.org/10.1007/s10460-020-10105-w

Gunderson, L. H., \& Holling, C. S. (Eds.). (2002). Panarchy: Understanding transformations in buman and natural systems. Washington, D.C.: Island Press.

Hamilton, A. J., Burry, K., Mok, H.-F., Barker, S. F., Grove, J. R., \& Williamson, V. G. (2014). Give peas a chance? Urban agriculture in developing countries. A review. Agronomy for Sustainable Development, 34(1), 45-73. https://doi.org/10.1007/s13593-013-0155-8

Hansen, N. (2020). COVID-19 has more people gardening; here's how to do it indoors. CBC News. Retrieved from https://www.cbc.ca/news/canada/saskatoon/indoor-gardening-pandemic-1.5535216

Harvey, M., Quilley, S., \& Beynon, H. (2002)._Exploring the tomato: Transformations of nature, society and economy. Cheltenham; Edward Elgar.

Haynes-Maslow, L., Hardison-Moody, A., \& Byker-Shanks, C. (2020). Leveraging informal community food systems to address food security during COVID-19. Journal of Agriculture, Food Systems, and Community Development, 10(1), 1-4. https://doi.org/10.5304/jafscd.2020.101.005

Hebrok, M. \& Boks, C. (2017). Household food waste: Drivers and potential intervention points for design- an extensive review. Journal of Cleaner Production, 151, 380-392. https://doi.org/10.1016/j.jclepro.2017.03.069

Hodgson, G. M. (2017). Karl Polanyi on economy and society: A critical analysis of core concepts. Review of Social Economy, 75(1), 1-25. https://doi.org/10.1080/00346764.2016.1171385

Homer-Dixon, T., Walker, B., Biggs, R., Crépin, A.-S., Folke, C., Lambin, E. F., Peterson, G. D., Rockström, J., Scheffer, M., Steffen, W., \& Troell, M. (2015). Synchronous failure: The emerging causal architecture of global crisis. Ecology and Society, 20(3), Art. 6. http://dx.doi.org/10.5751/ES-07681-200306

Ihle, R., Rubin, O. D., Bar-Nahum, Z., \& Jongeneel, R. (2020). Imperfect food markets in times of crisis: Economic consequences of supply chain disruptions and fragmentation for local market power and urban vulnerability. Food Security, 12, 727-734. https://doi.org/10.1007/s12571-020-01084-1 
James, D., Bowness, E., Robin, T., McIntyre, A., Dring, C., Desmarais, A. A., \& Wittman, H. (2021). Dismantling and rebuilding the food system after COVID-19. Journal of Agriculture, Food Systems, and Community Development, 10(2), 1-23. https://doi.org/10.5304/jafscd.2021.102.019

Jribi, S., Ben Ismail, H., Doggui, D., \& Debbabi, H. (2020). COVID-19 virus outbreak lockdown: What impacts on household food wastage? Environment, Development and Sustainability, 22, 3939-3955. https://doi.org/10.1007/s10668-020-00740-y

Kowalski, J. M., \& Conway, T. M. (2019). Branching out: The inclusion of urban food trees in Canadian urban forest management plans. Urban Forestry \& Urban Greening, 45, 126142. https://doi.org/10.1016/j.ufug.2018.05.012

Lal, R. (2020). Home gardening and urban agriculture for advancing food and nutritional security in response to the COVID-19 pandemic. Food Security, 12, 871-876. https://doi.org/10.1007/s12571-020-01058-3

Levkoe, C. Z., Ray, L., \& Mclaughlin, J. (2019). The Indigenous Food Circle: Reconciliation and resurgence through food in Northwestern Ontario. Journal of Agriculture, Food Systems, and Community Development, 9(Suppl. 2), 101-114. https://doi.org/10.5304/jafscd.2019.09B.008

Littman, M. (2020, July 9). World Central Kitchen keeps workers employed while feeding the hungry. Nashville Scene. Retrieved from https://www.nashvillescene.com/food-drink/features/article/21139393/world-central-kitchenkeeps-workers-employed-while-feeding-the-hungry

Meerow, S., \& Newell, J. P. (2019). Urban resilience for whom, what, when, where, and why? Urban Geography, 40(3), 309-329. https://doi.org/10.1080/02723638.2016.1206395

Miller, R. K. (2020). A 2020 synopsis of the cell-cultured animal industry. Animal Frontiers, 10(4), 64-72. https://doi.org/10.1093/af/vfaa031

Ontario Government. (2020, October 23). Ontario takes steps to ensure surplus food does not go to waste [News Release]. Retrieved from https://news.ontario.ca/en/release/58930/ontario-takes-steps-to-ensure-surplus-food-does-not-go-to-waste

Pappalardo, G., Cerroni, S., Nayga, Jr., R. M., \& Yang, W. (2020). Impact of Covid-19 on household food waste: The case of Italy. Frontiers in Nutrition, 7, 291. https://doi.org/10.3389/fnut.2020.585090

Peters, D. (2020). Ontario's food-security groups are getting creative during COVID-19. TVO. Retrieved from https:/ / www.tvo.org/article/ontarios-food-security-groups-are-getting-creative-during-covid-19

Piotrowski, M. (2019). People, flour, water, salt: Bread and community in urban public space (Master's thesis). University of Waterloo. Retrieved from http://hdl.handle.net/10012/14776

Polanyi, K. (1957a). Aristotle discovers the economy. In K. Polanyi, C. Arendsberg, \& H. Pearson (Eds.), Trade and market in the early empires: Economies in history and theory, (pp. 64-94). Chicago: Henry Regnery.

Polanyi, K. (1957b). The economy as instituted process. In K. Polanyi, C. Arendsberg, \& H. Pearson (Eds.), Trade and market in the early empires: Economies in history and theory, (pp. 243-270). Chicago: Henry Regnery.

Polanyi, K. (2001). The great transformation: The political and economic origins of our times (2nd ed.). Boston: Beacon Press.

Principato, L., Secondi, L., Cicatiello, C., \& Mattia, G. (2020). Caring more about food: The unexpected positive effect of the Covid-19 lockdown on household food management and waste. Socio-Economic Planning Sciences, 100953. https://doi.org/10.1016/j.seps.2020.100953

Quilley, S. (2012). System innovation and a new 'Great Transformation': Re-embedding economic life in the context of 'de-growth.' Journal of Social Entrepreneurship, 3(2), 206-229. https://doi.org/10.1080/19420676.2012.725823

Reynolds, C., Goucher, L., Quested, T., Bromley, S., Gillick, S., Wells, V.K., .. Jackson, P. (2019). Review: Consumption-stage food waste reduction interventions- what works and how to design better interventions. Food Policy, 83, 7-27. https://doi.org/10.1016/j.foodpol.2019.01.009

Richardson, R. (2020). Bending the arc of COVID-19 through a principled food systems approach. Agriculture and Human Values, 37, 653-654. https://doi.org/10.1007/s10460-020-10048-2

Riches, G. (2011). Thinking and acting outside the charitable food box: Hunger and the right to food in rich societies. Development in Practice, 21(4-5), 768-775. https://doi.org/10.1080/09614524.2011.561295

Roberts, W., \& Brandum, S. (1995). Get a life!- How to make a good buck, dance around the dinosaurs and save the world while you're at it. Get A Life Publishing House. 
Rotz, S., \& Fraser, E. D. G. (2015). Resilience and the industrial food system: Analyzing the impacts of agricultural industrialization on food system vulnerability. Journal of Environmental Studies and Sciences, 5, 459-473. https://doi.org/10.1007/s13412-015-0277-1

Savary, S., Akter, S., Almekinders, C., Harris, J., Korsten, L., Rötter, R., Waddington, S., \& Watson, D. (2020). Mapping disruption and resilience mechanisms in food systems. Food Security, 12, 695-717. https://doi.org/10.1007/s12571020-01093-0

Schanes, K., Dobernig, K., \& Gözet, B. (2018). Food waste matters- a systematic review of household food waste practices and their policy implications. Journal of Cleaner Production, 182, 978-991. https://doi.org/10.1016/j.jclepro.2018.02.030

Sexton, A. E., Garnett, T., \& Lorimer, J. (2019). Framing the future of food: The contested promises of alternative proteins. Environment and Planning E: Nature and Space, 2(1), 47-72. https://doi.org/10.1177/2514848619827009

Si, Z., Qi, D., Dai, N., Zhong, T., \& Crush, J. (2020). COVID-19 and grassroots community organizing in Wuhan, China (Research Brief No. 5). Retrieved from Hungry Cities Partnership website: https://hungrycities.net/wp-content/uploads/2020/08/Research-Brief-5.pdf

Specht, K., Siebert, R., Thomaier, S., Freisinger, U. B., Sawicka, M., Dierich, A., Henckel, D., \& Busse, M. (2015). Zeroacreage farming in the city of Berlin: An aggregated stakeholder perspective on potential benefits and challenges. Sustainability, 7(4), 4511-4523. https://doi.org/10.3390/su7044511

Specht, K., Zoll, F., Schümann, H., Bela, J., Kachel, J., \& Robischon, M. (2019). How will we eat and produce in the cities of the future? From edible insects to vertical farming-A study on the perception and acceptability of new approaches. Sustainability, 11(16), 4315. https://doi.org/10.3390/su11164315

Stephens, N., Di Silvio, L., Dunsford, I., Ellis, M., Glencross, A., \& Sexton, A. (2018). Bringing cultured meat to market: Technical, socio-political, and regulatory challenges in cellular agriculture. Trends in Food Science \& Technology, 78, 155-166. https://doi.org/10.1016/i.tifs.2018.04.010

Tendall, D. M., Joerin, J., Kopainsky, B., Edwards, P., Shreck, A., Le, Q. B., Kruetli, P., Grant, M., \& Six, J. (2015). Food system resilience: Defining the concept. Global Food Security, 6, 17-23. https://doi.org/10.1016/j.gfs.2015.08.001

Thyberg, K. L. \& Tonjes, D. J. (2016). Drivers of food waste and their implications for sustainable policy development. Resources, Conservation and Recycling, 106, 110-123. https://doi.org/10.1016/j.resconrec.2015.11.016

Tucker, R. (2020, August 10). How COVID-19 could forever change the way Ontarians buy food. TVO. Retrieved from https://www.tvo.org/article/how-covid-19-could-forever-change-the-way-ontarians-buy-food.

Wray, M. (2020, March 25). Community turns Little Libraries into food, toilet paper-sharing stops amid coronavirus. Global News. Retrieved from https://globalnews.ca/news/6730254/coronavirus-free-little-library-pantries/

Yaffe-Bellany, D. \& Corkery, M. (2020, April 11). Dumped milk, smashed eggs, plowed vegetables: Food waste of the pandemic. The New York Times. Retrieved from https://www.nytimes.com/2020/04/11/business/coronavirusdestroying-food.html 